\title{
速度に依存する繰返し塑性变形挙動” （不規則障害物説に基つく表示）
}

\author{
小幡 谷 \\ Rate-Dependent Behavior in Cyclic Plasticity \\ (Description Based on the Random Barriers Theory)
}

洋

\author{
by Yoichi OBATAYA
}

\begin{abstract}
A descriptive model for rate-or time-dependent behavior in cyclic plasticity, based on the random barriers theory, was presented by considering the velocity of a moving dislocation which was a member of movable dislocations and named as a "free dislocation" in this paper. Each of the stressand strain-rate sensitivities on the stress-strain relation in each half cycle could be fairly estimated on the basis of an equilibrium equation derived in this study as a function of the stress-rate and the strain-rate at any stress level. Moreover, several types of transient behavior caused by a sudden change in the stress-or strain-rate might be uniformly expressed by each analysis of the processes in which a deficient or excess quantity of the free dislocations in this period came near to the moderate quantity decided by the stress and stress-rate.
\end{abstract}

Key Words: Cyclic Plasticity, Dislocation Velocity, Rate Sensitivity, Field of Resisting Force

\section{1. 緒}

クリープ変形を無視できるような温度領域における 比較的ひずみ速度の低い綵返し塑性变形過程において も，例えば応力速度やひすみ速度が急減する場合には クリープ変形に類似の挙動や応力緩和挙動などの時間 に依存する塑性変形挙動の生ずることが Krempl ら によって実験的に示されている(1)(2).こうした本来塑 性変形に固有のものと思われる時間依存性の変形挙動 を記述するには，少なくともなんらかの形で塑性変形 機棈と関連させて検討することが望ましい.しかし， こうしな点については現在まてかならずしも十分明ら がされていると沽いえない。

そこて，本研究では鵜戸口・岡村によって提示され た不規則障害物説 ${ }^{(3)}$ を適用・発展させ、時間扝よび速 度に依存する綝返し塑性変形举動を記述するための一 つのモデルを提示し，繰返し応力ーひずみ曲線に及ほ す㐫力抢よびひずみ速度の効果，さらに負荷条件が急 変する際の時間に依存するさまざまな塑性変形沁答性 について検討した。

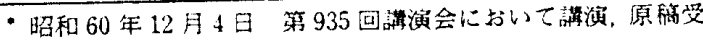
付 昭和 60 年 5 月 31 日。

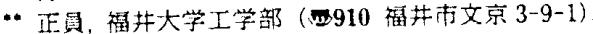

なお，不規則障害物説では，転位の移動に对してき まざまな大きさの抵抗力となる障害物を転位の位置お よびその移動方向に上って定まる不規則な波形をもつ 抵抗力場の山あるいは谷に対応させ，障害物強度の密 度分布で表現される抵抗力場内での転位の移動挙動を もとに塑性変形特性を記述している，著者および河野 はこうした密度分布の基本形としてワイブル分布を導 入し，時間 (速度)に依存しない繰返し塑性変形举動(4), および静引張応力ーひずみ曲線(5)などが抵抗力場の概 念を用いた手法によって総合的に表示てきることを示 してきた。しかし，その際力場の山を越して移動する 転位の速度は一律に無限に大きいという仮定を前提と していた。本研究では，転位の移動速度に限界のある ことを考虑し，力場の山を越す転位の速度は㐫力速度 に依存すると仮定している。

\section{2. 抵抗力場と応力ーひずみ関係式}

$2 \cdot 1$ 時間 (速度)に依存しない場合先に提示し た時間 (速度)に依存しない繰返し望性変形举動を記述 しうるモデル(4)のうち本研究と関連する部分を简単に 述べる。

両振り定ひずみ試験て図 1 (a)に破線で示す安定し たヒステリシスループを描くようになった後の変動ひ 
ずみ繰返し下における変形挙動を記述するにあたり， 過去に履歷した最大もしくは最小応力を起点とする応 力の尺度 $S$ を用いた. 任意の半サイクル始点 $\mathrm{E}(S=$ $\left.S_{o}\right)$ における抵抗力場すなわち変形に関与する障害物 強度の確率密度関数 (以下単に密度関数とよぶ) $h_{0}(\sigma)$ は応力 $S$ を変量とする分布中央值 $S_{c o}$, 形状のパラメ 一タ $m_{0}$ およ゙位置のパラメータが零であるワイブル 分布の確率密度関数で与えられるとし，これを簡単に $w\left(S ; S_{c o}, m_{0}\right)$ で表示した.すなわち,

$$
\begin{aligned}
& h_{0}(\sigma) \equiv w\left(S ; S_{c o}, m_{o}\right) \\
& \quad=\frac{m_{o} \ln 2}{S_{c o}}\left(\frac{S}{S_{c o}}\right)^{m_{0}-1} 2^{-\left(\frac{S}{S_{c o}}\right)^{m_{o}}}
\end{aligned}
$$

また, 応力履歷に伴う密度関数の変化特性に関する簡 単な仮定を用い, 点 $E$ よりはじまる半サイクルでの塑 性ひずみ $\varepsilon_{p}$ と応力 $S$ の関係を次式で与えた。

$$
A \varepsilon_{p}=2^{\left(S_{0} / S_{c o}\right) m_{0}}-2^{\left(S_{0} / S_{c o}\right) m_{0}} \text {. }
$$

ここて $A$ は内部構造変数であり, 変形に関与する单 位面積あたりの転位の数 $N$ ，転位のすべり方向単位長 さあたりの障害物の数 no, せん断塑性ひずみと軸方向 塑性ひずみの換算係数 $k$ ，およびバーガースベクトル の大きさ $b$ を用い次式で与えられるものである.

$$
A=n_{0} / k b N
$$

なお，Aの値は焼なまし材などの変形初期ではひずみ 履歴に大きく依存するが, 変形の進んだ段階でほぼー 定值となることをすてに先の研究(5)で示しており, 本 研究では $A$ の值がほぼ一定となった状態での場合に ついて検討する。

密度関数が与えられた場合, 抵抗力場内での転位の 移動挙動は以下のように記述できる，ho( に $g(S)$ とおきかえると, 障害物の総数 n。は

$$
n_{o}=\int_{-\infty}^{\infty} h_{o}(\sigma) d \sigma=\int_{0}^{\infty} g(S) d S
$$

で与えられる.ここで関数 $G(S) を$

$$
G(S)=\int_{s}^{\infty} g(S) d S=2^{-\left(S / s_{c o}\right) m_{0}}
$$

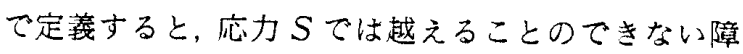
害物の数は $n_{0} G(S)$ であり, 応力 $S$ で障害物（力場の 山）を越した転位の移動できる平均距離 $h_{m}(S)$ は

$$
h_{m}(S)=1 / n_{0} G(S)
$$

で与えられる。図1（c）には力場の山を越してからの 転位の移動量 $x$ と応力 $S$ とを座標軸にとった $x-S$ 平面上に, $h_{m}(S)$ と $S$ の関係を模式的な曲線として 示した．力場の山を越した 1 個の転位がこの曲線に到 達した時点で生ずる巨視的塑性ひずみは $k b h_{m}(S) て ゙$ ある.一方, 変形に関与する $N$ 個の転位のうち $\delta N$ 個 が応力 $S$ から $S+\delta S$ の間 (図での NM 間)に力場の 山を越すものとすれば，その比 $\delta N / N$ は $\delta S$ 間に存
在する障害物の数 $\left[\doteqdot n_{0} g(S) \delta S\right]$ と応力 $S$ ては越す ことのできない障害物の数 $\left[=n_{0} G(S)\right]$ の比とほ㳊等 しいと考えることができる。したがって， $\delta N$ は $g(S)$ $=-d G(S) / d S$ に注意すると次式で与えられる.

$$
\delta N=N \frac{\{-d G(S) / d S\}}{G(S)} \delta S
$$

$\delta N$ 個の転位が即刻 $h_{m}(S)-S$ 曲線に到達するものと すれば，応力増加による塑性ひずみの増加率 $d \varepsilon_{p} / d S$ は $\delta S$ を微小と考え次式で与えられる。

$$
\frac{d \varepsilon_{p}}{d S}=\frac{g(S)}{A\{G(S)\}^{2}}
$$

$こ こ て$

$$
g(S) /\{G(S)\}^{2}=f(S)
$$

とおいた $S$ の单調增加関数 $f(S)$ を導入すると式 (8)は次式の上うに簡単に記述できる.

$$
A d \varepsilon_{p}=f(S) d S
$$

$A$ の值が一定の場合には式(10)より式 (2)の応力ーひ ずみ関保式を導くことは容易である。

\section{$2 \cdot 2$ 転位の速度を考慮する場合 ここでは力場} の山を越して移動中の転位をとくに自由転位と呼ふここ ととし，応力ーひずみ関係に及ほす自由転位の速度効 果について険討する.なお，自由転位以外の力場の斜 面上を移動する可動転位の速度はほぼ零に近いと考え ろ.

可動転位の平均移動速度については巨視的塑性ひず み速度と対応させて応力の大きさとの関保て議論され る場合が多く，個々の転位の移動速度に関しては必ず しも明らかにされてはいない. Jhonstonら は成灾力ハ ルスを与えて移動した転位の移動距離を観測し、これ を応力を加えた時間で除して個々の転位の速度を求 め, それらを加えた応力の大きさとの関係で挨討して いる。しかし，転位の移動に要した時間は必ずしも明 確と流いえないので評価された值は実際の転位の速度 よりも小さく見積もられている可能性もある。また， そうして得られた転位速度が応力の継続時間に必ずし

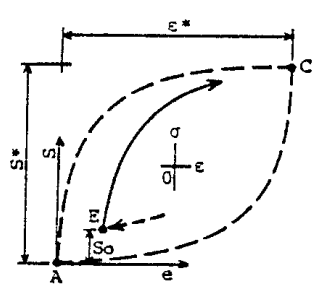
(a) Stress-gtrain
relation

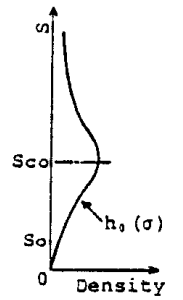

(b) Distribution of strength of barrier

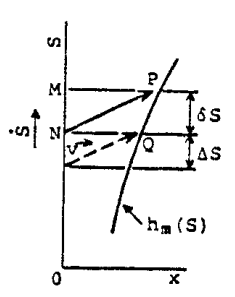

(c) $h_{m}(s)-s$ curve
図 1 応力ーひずみ曲線と抵抗力場における 転位の移動挙動（説明図） 
も依存していないという観察事夷を考えるなら，個々 の転位の移動速度は応力の大きさよりももしろ応力速 度に依存すると考えていいように思われる。

そこで本研究では個々の自由転位の移動速度 $v は$ 力場の山を越す際の巨視的せん断応力速度 $\dot{\tau}$ に依存 し，次式によって与えられるものと仮定する。

$$
v / v_{c}=\left(\dot{\tau} / C \rho v_{c}\right)^{n}
$$

ここて， $v_{c}$ は弾性横波の速度， $\rho$ は結晶の密度，nは 材料定数とする。な招，C岓応力の伝播速度にも限界 のあることを考慮して式(11)が常に $v<v_{c}$ を満足す るように定められる换算定数と考える，以下では，一 般的な垂直応力速度 $\dot{\sigma}(\equiv \dot{S})$ と定数 $\eta$ を用いて式 (11)が次式でおきかえられるものとして議論を進め ろ.

$$
v / v_{c}=\eta(\dot{S})^{n}
$$

図1(a)に示す点 $E$ からはじまる任意の半サイク ルでの応力とひずみの関係に及伊す転位の速度効果に ついて図 1 (c) に示す $h_{m}(S)-S$ 曲線を参照しながら 説明寸る。なお, 応力速度仙密度関数の变化特性に直 接的な影響を与えないものと仮定する。いま，応力速 度が $S$, 塑性ひずみ速度が主っである応力レベル $S$ (図 中点 N) で力場の山を越して速度 $v$ となった自由転位 が $\delta t$ 秒後に応力が $\delta S$ 増加した次の山の斜面 (点 P) に到達するとすれば次の関係式が成り立つ.

$$
\begin{aligned}
& v \delta t=h_{m}(S)+\left\{\partial h_{m}(S) / \partial S\right\} \delta S \\
& \dot{S} \delta t=\delta S \quad \ldots \ldots \ldots \ldots \ldots \ldots \ldots \ldots \ldots \ldots \ldots \ldots \ldots \ldots \ldots
\end{aligned}
$$

一方, 応力 $S$ で力場の山の斜面に到達した自由転位 は $t_{\mathrm{c}}$ 秒前に応力レベルが $S-\Delta S$ で力場の山を越した ものであるとすれば次の関係式が成り立つ.

$$
\begin{aligned}
& v t_{c}=h_{m}(S) \\
& \dot{S} t_{c}=\Delta S
\end{aligned}
$$

以上の諸式より $\Delta S$ は次式で与えられる.

$$
\Delta S=\left\{1-\frac{\dot{S}}{v} \cdot \frac{\partial h_{m}(S)}{\partial S}\right\} \delta S .
$$

この応力增分 $\Delta S$ の間に力場の山を越す転位の数 $\delta N$ は式( 7 )の関係を考慮し, 次式で与えられる。

$$
\delta N=N \frac{g(S)}{G(S)} \Delta S
$$

これら $\delta N$ 個の自由転位が $\delta t$ 秒間にすべて次の山の 斜面に到達するので，この間に生ずる塑性ひずみ増分 $\delta \varepsilon_{p}$ は自由転位の平均移動距晟を $h_{m}(S)$ と考え次式 で与えられる。

$$
\delta \varepsilon_{\rho}=k b \delta N h_{m}(S)
$$

ここで, $\dot{\varepsilon}_{p} \equiv \delta \varepsilon_{p} / \delta t, h_{m}(S)=1 / n_{o} G(S), A=n_{o} /$ $k b N$ および $\partial h_{m}(S) / \partial S=f(S) / n_{o}$ などの関係を考慮 すると次式を得る。

$$
\dot{\varepsilon}_{p}=\frac{\dot{S} f(S)}{A}\left\{1-\frac{\dot{S} f(S)}{n_{o} v}\right\}
$$

式（20）は抵抗力場の概念に基づく転位の速度効果を考 密した応力速度と塑性ひずみ速度の間に成り立つ速度 平衡式である。なお，式(12)を用いると式(20)は

$$
\dot{\varepsilon}_{p}=\frac{\dot{S} f(S)}{A}\left\{1-\frac{(\dot{S})^{1-n} f(S)}{n_{o} v_{c} \eta}\right\}
$$

となる、一方, 繰返し塑性変形試験においては弾性変 形が支配的となる変形反転直後の過程が必然的に含ま れるので，そうした場合には全ひずみ速度 $\dot{\varepsilon}_{t}$ が弾性 ひずみ速度 $\dot{\varepsilon}_{e}$ と $\dot{\varepsilon}_{p}$ の和で与えられるとして得られ る次式が適用できる。

$$
\begin{aligned}
\dot{\varepsilon}_{t} & =\dot{\varepsilon}_{e}+\dot{\varepsilon}_{p} \\
& =\left\{\frac{f(S)}{A}+\frac{1}{E}\right\} \dot{S}-\frac{(\dot{S})^{2-n}\{f(S)\}^{2}}{A n_{o} v_{c} \eta}
\end{aligned}
$$

\section{ここで，Eは絴弾性係数である.}

なお，式(20)の成立する前提は適正な数の自由転位 が存在することであり，そうした場合の変形をここで は定常変形と呼ふことどする。したがって，式(21)お よび式(22) 泣それそれ定常変形下てのという条件付き の塑性および弾塑性変形に対する構成式であるといえ る. 定常変形過程て必要な自由転位の数は応力レベル $S$ に依存するのでこれを $N d(S)^{*}$ で表示すると, 式 (18)ての $\delta N$ がこれに相当し, 次式で与えられる.

$$
N d(S)^{*}=N \frac{(\dot{S})^{1-n} f(S)}{n_{o} v_{c} \eta}
$$

したがって，式(21)および式(22)は $N d(S)^{*} を$ 用いて 次のように畫き換えることもできる。

$$
\begin{aligned}
& \frac{A \dot{\varepsilon}_{p}}{S f(S)}=\frac{A}{f(S)} \cdot \frac{d \varepsilon_{p}}{d S}=1-\frac{N d(S)^{*}}{N} \cdots \cdots(24) \\
& \frac{A \dot{\varepsilon}_{t}}{S f(S)}=\frac{A}{f(S)} \cdot \frac{d \varepsilon_{t}}{d S}=\frac{A}{E f(S)}+\left\{1-\frac{N d(S)^{*}}{N}\right\}
\end{aligned}
$$

以上のことより，先に示した式(10)は自由転位の存在 を無視した場合のものに相当しているといえる。

いま，A实と $\dot{S} f(S)$ をそれそれ縦軸および横軸に とり，転位の速度 $v$ をパラメータとして式(20)の関係 を図示すると図 2 に示すような各頂点が $\left(n_{o} v / 2\right.$, $\left.n_{o v} / 4\right)$ で与えられる放物線群となる。放物線上の任意 の点と原点とを結ぶ直線の傾斜は全可動転位にしめる 自由転位以外の可動転位の割合を示すものであり，各 頂点は全可動転位の半数が自由転位である状態に対応 している。もし自由転位の数をこれ以上增加させよう とすると，例えば $v=$ 一定のときにはひずみ硬化率が 急増したのち急速に直線 $A \dot{\varepsilon}_{p}=0 に$ 到達して変形が 停止するなど, 通常の繰返し塑性変形試験てはみられ ない举動を示すこととなる。したがってここては各頂 
点を結ふ直線を一つの限界線と仮定する，すなわち， 式(20)の成立するのは $v=v_{c}$ となる放物線と直線 $2 A \dot{\varepsilon}_{p}=\dot{S} f(S)$ とで囲まれる領域内に限られるものと する。

一方, 負荷条件の急変などにより定常変形に必要な 式(23)で与えられる $N d(S)^{*} に$ 対して自由転位に過 不足が生ずる場合には一時的に式(20)の平衡関係が破 れるのて，材料は時間に侾存する過渡的変形応答を示 すものと考えられ，そうした変形を以下ては䧣移変形 と呼ぶこととする.

\section{$2 \cdot 3$ 定常变形 定常変形過程中での任意の応力}

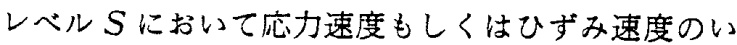
ずれか一方が与えられるならば，それらに適合したひ ずみ速度もしくは応力速度は式(21)あるいは式(22)上 り決定できる、したがって，その応力レベルでのひず み硬化率が式(24)あるいは式(25)より決定でき, 直後 での応力とひずみの関係が定まる，以上の操作を負荷 条件に応じて継続することにより定常変形学動を完全

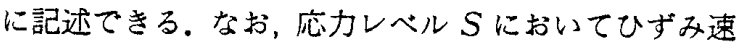
度が与えられた場合, 式(21)あるいは式(22)上り応力 速度 Sの解はそれぞれ二つ得られるが，それらのう ちの值の小さいほうが実現する解と考える。

一方, 図 3 に示寸限界線 $2 A \dot{\varepsilon}_{p}=\dot{S} f(S)$ に達した後 は自由転位が全可動転位の半数を維持したまま変形が 進展するものと仮定し，ひずみ硬化率は式(24)より求 まる次式で与えられるものとする。

$$
\frac{d S}{d \varepsilon_{p}}=\frac{2 A}{f(S)}
$$

限界線に達した時点での応力を $S_{n}$, 塑性ひずみを $\varepsilon_{\rho n}$ とすれば，その後の応力と塑性ひずみの関係は次式で 表される.

$$
\begin{array}{r}
2 A\left(\varepsilon_{p}-\varepsilon_{p_{n}}\right)=\int_{S_{n}}^{S} f(S) d S \\
\quad=2^{\left(S / S_{c o}\right)^{m_{0}}}-2^{\left(S_{n} / S_{c o} m^{m_{0}}\right.} \ldots \ldots .
\end{array}
$$

なお，繰返し塑性変形試験において定常変形の実現す るのは少なくとも変形反転淔後の遷移変形ののちであ ることを付言しておく.

$2 \cdot 4$ 畺移变形 変形反転時あるいは定常変形過 程中でも忘力速度あるいはひずみ速度の急変により式 （20）の平衡関係が一時的に破れる場合には, 負荷条件 に応じた抵抗力場内での自由転位の移動挙動を個々に 榙討する必要がある．以下ではとくにことわら姷り， $\left\{\right.$ 応力： $S_{1}$, 応力速度： $\dot{S}_{1}$, 塑性ひずみ速度： $\dot{\varepsilon}_{p_{1}}$, 転 位速度： $\left.v_{1}\right\}$ の定常変形の段階で負荷条件を急変し， 一定時間後に次の定常変形 $\left\{S_{2}, \dot{S}_{2}, \dot{\varepsilon}_{p 2}, v_{2}\right\}$ に至る場 合を考え，この間での既移変形過程をいくつかの代表
的な負荷急変条件に対し, 図 3 に示す $h_{m}(S)-S$ 曲線 を用いて説明する。なお，遷移变形前後での自由転位 の数 $N d\left(S_{1}\right)^{*}$ おび $N d\left(S_{2}\right)^{*}$ は式(23)で与えられて いるものとする。

2・4・1 S が急增する場合 [図 3(a)] $N d\left(S_{1}\right)^{*}$ $<N d\left(S_{2}\right)^{*}$ の場合であるから，急增した応力速度に 適合する定常変形下ての塑性ひずみをただちに生ずる ことはできず，ひずみ硬化率は急增する，いま，応力 レベル $S_{1}$ て山を越した速度 $v_{2}$ の自由転位が $t_{c}$ 秒後 に㐫力レベル $S_{2}$ で次の山の斜面に到達した時点を遷 移変形の終了時と仮定する。この間応力速度は $\dot{S}_{2}$ て 一定であるので次の関係式が成り立つ。

$$
\begin{aligned}
& v_{2} t_{c}=h_{m}\left(S_{2}\right)=1 / n_{o} G\left(S_{2}\right) \text {. } \\
& \dot{S}_{2} t_{c}=S_{2}-S_{1}
\end{aligned}
$$

以上の二式より $t_{c}$ を消去すると，

$\left(\dot{S}_{2}\right)^{1-n} / n_{o} v_{c} \eta=G\left(S_{2}\right) \cdot\left(S_{2}-S_{1}\right)$

となり， $S_{2}$ を求めることができる。なお，この間に生 ずる塑性ひずみ $\varepsilon_{p c}$ は $N d\left(S_{1}\right)^{*}$ 個の自由転位がすへ

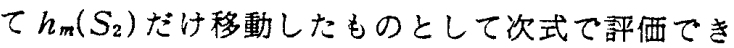
る.

$$
\begin{aligned}
\varepsilon_{p c} & =k b N d\left(S_{1}\right)^{*} h_{m}\left(S_{2}\right) \\
& =\left\{\left(\dot{S}_{1}\right)^{1-n} f\left(S_{1}\right)\right\} / A n_{o} v_{c} \eta G\left(S_{2}\right)
\end{aligned}
$$

2・4.2 $\dot{S}$ が急隇する場合 (図 $3(\mathrm{~b})$ ) 速度 $v_{1}$ で移動している $N d\left(S_{1}\right)^{*}\left[>N d\left(S_{2}\right)^{*}\right]$ 個の自由転位 は減速されずに $t_{c 1}$ 秒後までにすへてて次の山の斜面に 到達するものとし，その終了時の応力を $S^{\prime}$ とする.こ の間応力速度は $S_{2}$ であるから，

$$
\begin{aligned}
& v_{1} t_{c 1}=h_{m}\left(S^{\prime}\right)=1 / n_{0} G\left(S^{\prime}\right) \\
& \dot{S}_{2} t_{c 1}=S^{\prime}-S_{1} \ldots \ldots \ldots \ldots \ldots \ldots
\end{aligned}
$$

の二式より得られる次式によって $S^{\prime}$ が求まる.

$$
\dot{S}_{2} /\left\{n_{o} v_{c} \eta\left(\dot{S}_{1}\right)^{n}\right\}=G\left(S^{\prime}\right)\left(S^{\prime}-S_{1}\right)
$$

この間で生ずる塑性ひずみ $\varepsilon_{p c}$ は式(31)の $S_{2}$ を $S^{\prime}$ におきかえた式によって与えられる。

一方，応力速度を急減した直後に山を越した速度 $v_{2}$ の自由転位が $t_{c 2}\left(>t_{c 1}\right)$ 秒後に応力レベル $S_{2} に お い$ て山の斜面に達し，この時点が邉移変形の終了時と仮

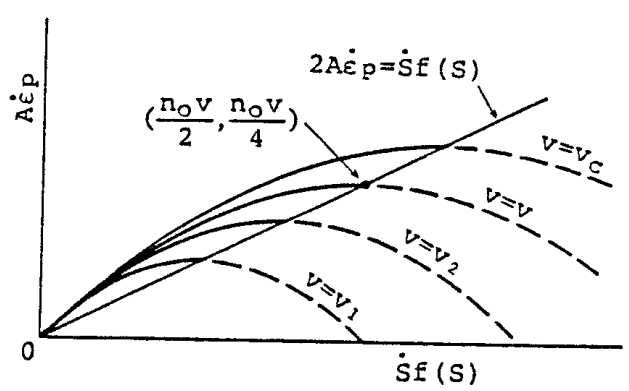

図 2 式(20)における $A \dot{\varepsilon}$ とと $\dot{S} f(S)$ の関倸図 
定すれ法， $S_{2}$ は式(30)で与えられるものに等しい。な お，応力が $S^{\prime}$ から $S_{2}$ まで增加する間では新たに斜 面に到達する自由転位は存在しないので塑性ひずみは 生じない.

2・4・3 S が零となる場合 [図 3(c)]ここでは， 自由転位の减速の効果を考慮して検討してみる，速度 $v_{1}$ で移動中の $N d\left(S_{1}\right)^{*}$ 個の自由転位は応力速度を零 とした時点より隇速しはじめるが，次々と山の斜面に 到達して塑性ひずみを生じさせることとなる。Sを需 としてから $t$ 秒後の転位の速度 $v$ は次式で与えれ るものとする。

$$
v=v_{1} \exp \left(-\zeta n_{0} v_{1} t\right)
$$

ここでちは定数とするが, $t$ にかかる $\left(n_{o} v_{1}\right)$ の項は $\zeta$ を無次元化する意味と，S を零とした直後の転位の 移動に対する抵抗力の大きさが $n_{0} v_{1}$ に比例するもの と考えて導入した。

いま， $t=0$ において自由転位は $h_{m}\left(S_{1}\right)$ の間に均等

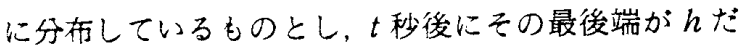
け移動しているものとする。ひきつづく $\delta t$ 秒間にそ

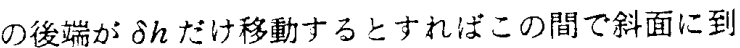
達する自由転位の数 $\delta N$ は, $\delta h=v \delta t$ の関係に注意 して次式で与えられる。

$$
\delta N=N d\left(S_{1}\right)^{*} v \delta t / h_{m}\left(S_{1}\right)
$$

したがって， $\delta t$ 秒間で生ずる塑性ひずみ增分 $\delta \varepsilon_{0}$ は

$$
\begin{aligned}
& \delta \varepsilon_{\rho}=k b \delta N h_{m}\left(S_{1}\right) \\
& \quad=\dot{S}_{1} f\left(S_{1}\right) \exp \left(-\zeta n_{o} v_{1} t\right) \delta t / A
\end{aligned}
$$

となり， $t$ 秒後までに生ずる塑性ひずみ $\varepsilon_{p}$ は

$$
\varepsilon_{p}=\frac{\dot{S}_{i} f\left(S_{1}\right)}{A \zeta n_{o} v_{1}}\left\{1-\exp \left(-\zeta n_{o} v_{1} t\right)\right\}
$$

で与えられる。式(38)に基づく変形特性はクリープ変 形挙動に類似しているが，自由転位がすべて山の斜面 に到達した時点で変形が停止する点に特徽がある。変

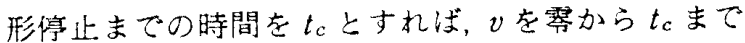
時間で積分した值が $h_{m}\left(S_{1}\right)$ に等しいことに注意する と $t_{c}$ 㳉次式で与えられる。

$$
t_{c}=-\frac{\ln \left\{1-\zeta / G\left(S_{1}\right)\right\}}{\zeta n_{o} v_{c} \eta\left(S_{1}\right)^{n}}
$$

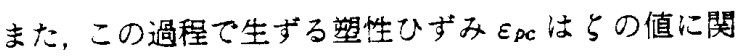
係なく次式でえられる。

$$
\varepsilon_{p c}=\left(\dot{S}_{1}\right)^{1-n} f\left(S_{1}\right) / A n_{o} v_{c} \eta G\left(S_{1}\right)
$$

2.4.4 $\dot{\varepsilon}_{\text {t }}$ が急增する場合〔図 $\left.3(\mathrm{~d})\right\}$ 速度 $v_{1}$ なる $N d\left(S_{1}\right) *$ 個の自由転位注急増後のひずみ速度 $\dot{\varepsilon}_{t 2}$ に追従しうるよう加速の必要があり応力速度も急 增する、いま，遥移変形過程での応力速度を $\dot{S}_{0}$ とし， これは自由転位の数を近似的に無視した式(22)の速度 平衡式によって与えられるものと仮定する。すなわ ち,

$$
\dot{S}_{0} \fallingdotseq A \dot{\varepsilon}_{t 2} /\left\{f\left(S_{1}\right)+A / E\right\}
$$

したがって，自由転位の速度 voは式(12)で与えられ る. 速度 $v_{0}$ に加速された自由転位か $t_{c}$ 秒後に応力 $S_{2}$ ての斜面に到達した時点を遷移変形の終了時とすれ ば,

$$
\begin{aligned}
& v_{o} t_{c}=h_{m}\left(S_{2}\right) \\
& \dot{S}_{0} t_{c}=S_{2}-S_{1}
\end{aligned}
$$

より，応力 $S_{2}$ 在与える次の関係式を得る。

$\left(\dot{S}_{0}\right)^{1-n} / n_{o} v_{c} \eta=G\left(S_{2}\right)\left(S_{2}-S_{1}\right)$

この闃で生ずる塑性ひずみ $\varepsilon_{p c}$ は式 (31)で与えられる ものと等しい.

なお，繰返し塑性変形下の変形反転直後では自由転 位存在しないので $N d\left(S_{1}\right)^{*}=0$ とおけばよく，その 際応力 $S_{2}$ までの間では塑性変形を生じない.

$2 \cdot 4 \cdot 5 \dot{\varepsilon} \rho$ が急隇する場合〔図 3(e )〕この過程 ては応力低下を伴うが，その低下量は小さいので弾性 ひずみを一定と仮定し，以下で示すような単純化した 二つの段階に分けて検討する。速度 $v_{1}$ の自由転位はひ ずみ速度を急減してもただちに停止せず，正方向に過 剩な塑性しずみを生じようとし、これを補正するよう 自由転位以外の $\left\{N-N d\left(S_{1}\right)^{*}\right\}$ 個の可動転位は力場 の斜面を負方向に移動する必要があり，応力は一時的 に $S^{\prime}$ まで低下する．以上の過程を第一段階とする。 $N d\left(S_{1}\right)^{*}$ 個の自由転位が $\delta t$ 秒間にすべて応力 $S^{\prime}$ の

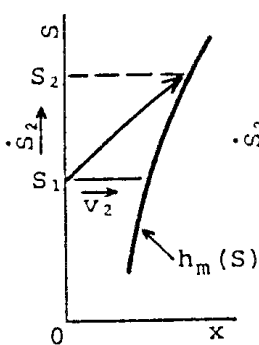

(a) $\dot{\mathrm{S}}_{2}>\dot{\mathrm{S}}_{1}$

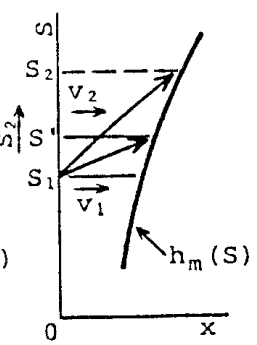

(b) $\dot{S}_{2}<\dot{S}_{1}$

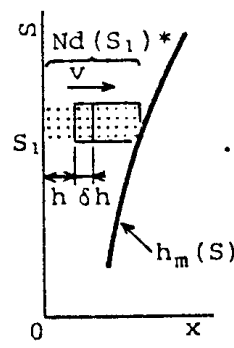

(c) $\dot{S}_{2}=0$

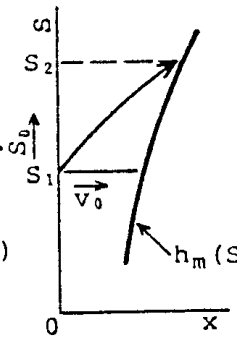

(d) $\dot{\varepsilon}_{\mathrm{t}_{2}}>\dot{\varepsilon}_{\mathrm{t}}$

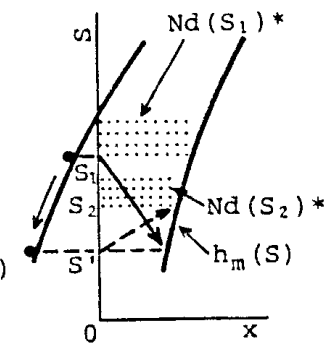

(e) $\dot{\varepsilon} p_{2}<\dot{\varepsilon} p_{1}$

図 3 要移変形過程に拈ける抵抗力場内での自由転位の移動劳動（説明図） 
斜面に到達しているとすれば，その移動によって期待 される正方向の塑性ひずみ增分 $\delta \varepsilon_{p}^{+}$は次式で与えら れる。

$$
\delta \varepsilon_{p}^{+}=k b N d\left(S_{1}\right)^{*} h_{m}\left(S^{\prime}\right) .
$$

一方, この間斜面を下る可動転位の移動によって期待 される負方向の塑性ひずみ增分 $\delta \varepsilon_{p}^{-}$は

$$
\delta \varepsilon_{p}^{\bar{p}}=k b\left\{N-N d\left(S_{1}\right)^{*}\right\}\left\{h_{m}\left(S_{1}\right)-h_{m}\left(S^{\prime}\right)\right\}
$$

て与えられる。したがって実質的な正方向の塑性ひず

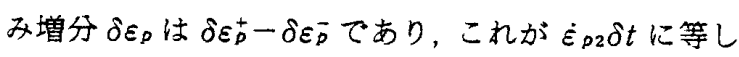
いと考えることができる。すなわち，

$$
\delta \varepsilon_{p}=\delta \varepsilon_{p}^{+}-\delta \varepsilon_{p}^{-}=\dot{\varepsilon}_{p 2} \delta t
$$

また,ひずみ速度急減直前に山を越した速度 $v_{1}$ の自 由転位は $\delta t$ 秒で丁度応力 $S^{\prime}$ の斜面に到達するので， この間転位の減速効果を無視すれば次式を得る。

$$
v_{1} \delta t=h_{m}\left(S^{\prime}\right)
$$

以上の諸式より応力 $S^{\prime}$ をえる次式が得られる.

$$
\left\{1-\frac{A \dot{\varepsilon}_{\rho 2}}{n_{0} v_{1}}\right\} \frac{1}{G\left(S^{\prime}\right)}=\left\{1-\frac{\dot{S}_{1}\left(S_{1}\right)}{n_{o} v_{1}}\right\} \frac{1}{G\left(S_{1}\right)} \text { (49) }
$$

この第一段階で生ずる塑性ひずみ $\varepsilon_{p c}^{\prime}$ は

$$
\varepsilon_{p c}^{\prime}=\dot{\varepsilon}_{p 2} \delta t=\frac{\dot{\varepsilon}_{p 2}}{v_{1}} h_{m}\left(S^{\prime}\right)
$$

でえられる。

以上の第一段階につづき，第二段階は自由転位の存

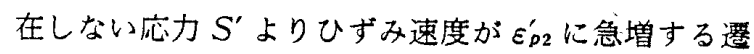
移変形過程を想定する．その際の挙動は $2 \cdot 4 \cdot 4$ 項で示 した手法を用いて解析できる。すなわち，この場合

$$
\dot{S}_{0}=A \dot{\varepsilon}_{p_{2}} / f\left(S^{\prime}\right)
$$

とおき，応力 $S_{2}$ は次式より求めることができる.

$$
\left(\dot{S}_{0}\right)^{1-n} / n_{0} v_{c} \eta=G\left(S_{2}\right)\left(S_{2}-S^{\prime}\right)
$$

以上の第一および第二段階は極めて短時間で終了する と考えられるので,ここではこれらを重稀あせ，忘 力 $S_{1}$ 加応力 $S_{2}$ まての遷移変形過程とする。 なお, 第二段階では塑性ひずみが生じないので，この悉移変

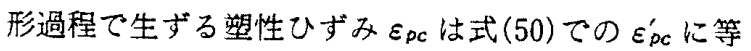
しい.

$2 \cdot 4 \cdot 6 \quad \varepsilon_{0}$ が零となる場合 これは, $2 \cdot 4 \cdot 5$ 項に おける第一段階で終了する場合に相当し, 応力 $S^{\prime}$ は 式(49)て $\dot{\varepsilon}_{\rho 2}=0$ とした式より決定できる.なお, 応力 低下量 $\Delta S=S_{1}-S^{\prime}$ は一般に $S_{1}$ に比べ充分小さいの で,上で得た式をもとに近似的に $\Delta S$ を与える次の関 保式を導くことができる。

$$
\Delta S / 2^{\left(S_{1} / S_{c o}\right) m_{0}}=\left(\dot{S}_{1}\right)^{1-n} / n_{o} v_{c} \eta
$$

式(53)は繰返し塑性変形過程で変形を停止した際に観 察される応力低下量が応力 $S_{1}$ と応力速度 $\dot{S}_{1}$ の大き さに依存していることを示すものである.

\section{3. 材料定数の決定とシミュレート計算例}

先の解析過程で明らかなように, $\left(n_{o} v_{c} \eta\right)$ の項は一 つの材料定数とみなしうるものてあった。 $2 \cdot 4 \cdot 6$ 項に 示した負荷条件による実験結果より定数 $n$ と $n_{0} v_{c} \eta$ とを容易に分離して決定できる. 先の研究(4)ての村料 と同じ炭素鍴での実駼結果より求まる式(53)での左边 の値を $\beta$ と招き， $\beta$ と $\dot{S}_{1}$ の関係を図 4 に示す.亮験点 はややばらつくが，両対数方眼紙上でほ沽直線関保を 示しており， $n \doteqdot 0.06$ および $n_{0} v_{c} \eta \doteqdot 6.54$ と評価する ことができた。なお，試験条件は塑性ひずみ幅を約 $2.5 \%$ とした両振り定ひずみ試験を基本とし，抵抗力 場を与える $S_{c o}$ と $m_{0}$ の值はひずみ速度を $10^{-4} \mathrm{sec}^{-1}$ とした際の安定したヒステリシスループの形状より式 (2)での $S 。$ を零, おょび $A$ を 1000 として求めた值 を用いた. $S_{c o}$ と $m_{0}$ の平均的な值はそれぞれ 570 $\mathrm{MPa}$ および 3.5 であり，以下に示すいずれのシミュ レート計算例もこれらの值で定まる抵抗力場のもとで のものである。なお，上で得た材料定数の活か縦弾性 係数 $E$ の值は $220 \mathrm{GPa}$ とした。

図 5 は半サイクルでの応力ーひずみ曲線の形状に及 活寸全ひずみ速度の効果を示す計算例である。10 10-4 $\mathrm{sec}^{-1}$ 以下のひずみ速度における曲線はひずみの全領 域にわたって式(10)て与えられる曲線（図では10 10 $\sec ^{-1}$ の曲線に対応)とほとんど重なりあっている。こ のことは例えば Krempl らが実験的に示している(1) $10^{-7} \mathrm{sec}^{-1}$ 程度のひずみ速度では曲線がさらに低応力 側に変化するという傾向とは必ずしも一致はしていな い.しかし，極端にひずみ速度の低い場合の変形举動 には，例えば熱振動による力場の山を越す転位の効果 も関与するのてはないかと著者は考えている。

図 6 は一定の塑性ひずみを生じさせるに必要な応力

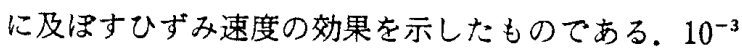
$\mathrm{sec}^{-1}$ をこえる付近でいったん速度依存性の增加する

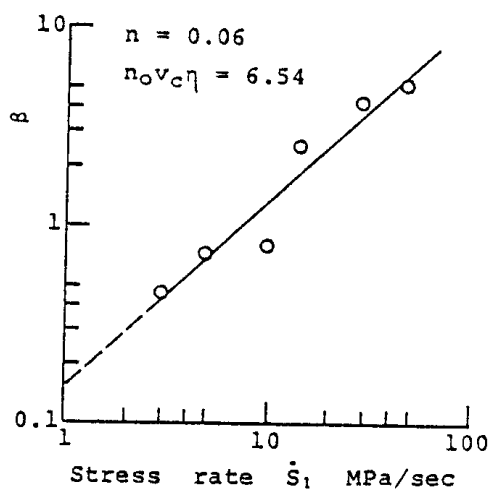

図 $4 \beta$ と $\dot{S}_{1}$ の関係（炭素銅） 
挙動がみられ、これが一般的なものなのかあるいは特 定の抵抗力場の場合に限られるものなのかなどについ ては今後検討を要することと思われる。しかし，さら にひずみ速度が大きくなるにつれ，とくにひずみの小 さい領域ての速度依存性が顥著に增大する傾向は，例 えば Nadai が軟鋼の静引張応力ーひずみ曲線に及注す ひずみ速度の効果を示した結果 ${ }^{(7)}$ に類似したものとな っている，以上の計算例でみるかきり，ヒステリシス ループの形状に及ほすひずみ速度の効果は $10^{-4} \mathrm{sec}^{-1}$ 以下ではほとんど考慮する必要はないが，低サイクル 疲れ試験などで通常広く用いられているひずみ速度 $10^{-3} \mathrm{sec}^{-1}$ になると一定程度その影響が現れてくるも のと考えられる。

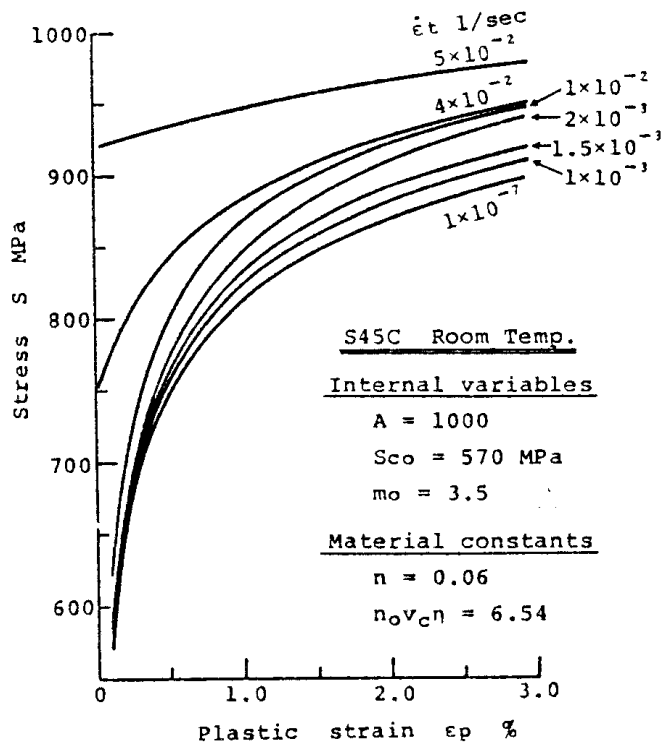

図 5 応力ーひずみ曲線に及ほすひずみ速度の効果

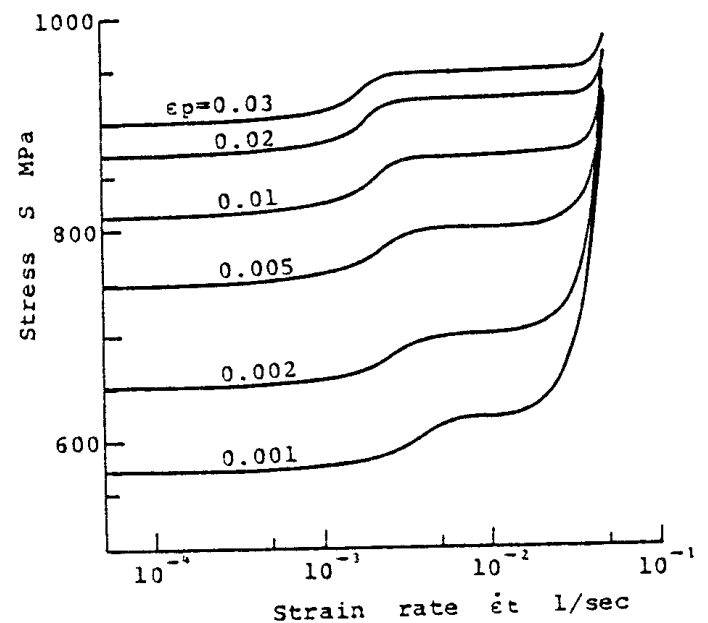

図 6 一定の塑性ひずみを生じさせる応力とひずみ 速度の関係（図6ての結果に基づく）
図7に示す太実線はひずみ速度を急変させた際の遷 移変形扔よび定常変形の挙動を示す計算例である。ひ ずみ速度の急增および急減直後の遷移変形に続く定常 変形過程での挙動はひずみ速度交一定とした図中に細 実線で示寸曲線にそれぞれかなり近づいていることが わかる.なお，ひずみ速度が $1.5 \times 10^{-3} \mathrm{sec}^{-1}$ から $10^{-3}$ $\mathrm{sec}^{-1}$ 人急隇した際の遷移変形過程でみられる大きな 塑性ひずみの生じている挙動はその直前に多数の自由 転位が存在していたためである。一方，図８に示す応 力を急変させた過程を含む場合の計算例ては，図 7 に みられる変形特性と比べ遷移変形過程での応答性がや や過度に強調されているようにみえる。しかし，全体 としての変形挙動は本モデルでの考え方でよく説明さ れているといえよう。

なお，図 8 における点 $h$ の段階て応力速度を零とし たのちの時間に依存した変形挙動を，らの値を変えた 式(38)によって計算した例を図 9 に示す。この変形過 程で最終的に生ずる塑性ひずみ量 $\varepsilon_{p c}$ はらの值によ らず一定であるが，変形終了までの時間および変形曲 線の形状は図に示すようにらの值によって異なって

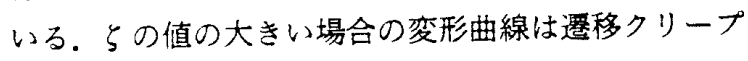
変形特性に類似しており，Kremplらが実験的に示し

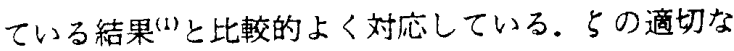
值は, $2 \cdot 4 \cdot 3$ 項で示した負荷条件による系統的な試験 により評価できるものと考えられる.

以上ここで示したいくつかのシミュレート計算例を みるかぎり，さらに検討すべき細かな点はあるにして も時間 (速度)に依存する塑性変形挙動は抵抗力場内て の自由転位の移動挙動という単一の機構を想定するこ とにより統一的に記述できるものと考えられる。なお， 繰返しに伴う抵抗力場の変化特性は先に提示した(4)綝 返し塑性変形モデルをそのまま適用して評価できると 考えている。

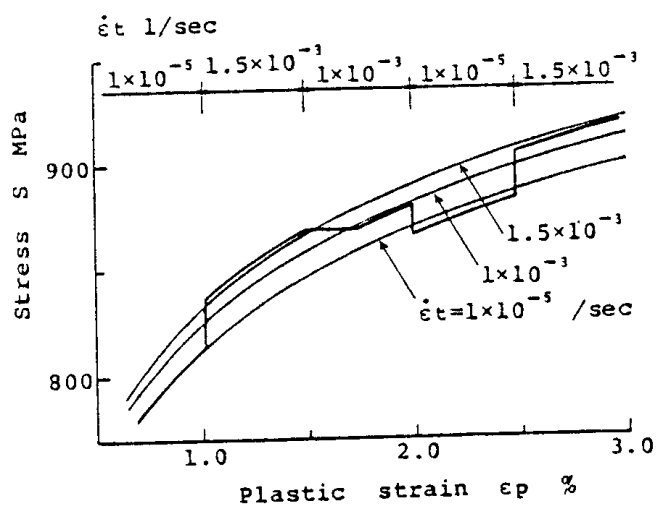

図 7 Uずみ速度急変過程を含む変形挙動の例 


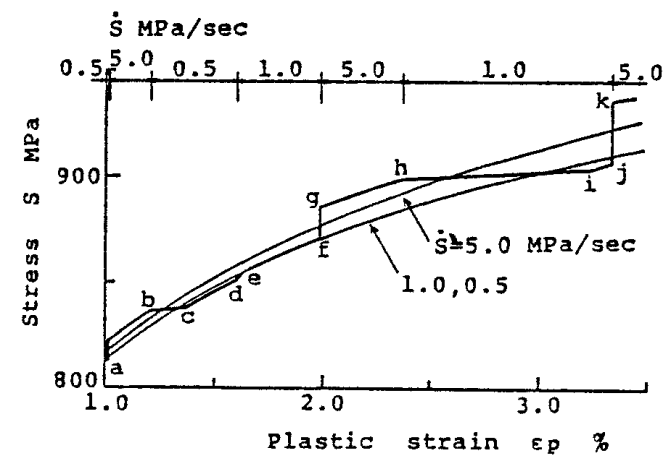

図 8 応力速度急変過程を含む変形学動の例

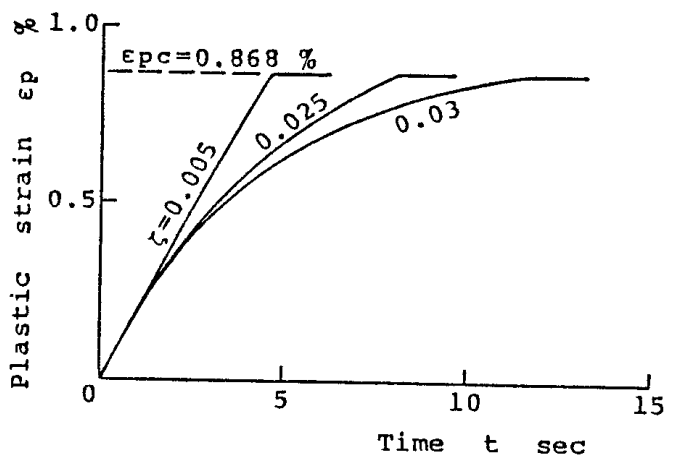

図 9 芯力速度を零とした後の変形挙動（始点 は図 8 での点 $\mathrm{h}$ )

\section{4. 結言}

不規則障害物説における抵抗力場内を移動する転位 の速度効果を考慮し，あらたに“自由転位”の概念を導 入することによって時間(速度)に依存する繰返し塑性 変形挙動を記述しうるモデルを提示し，その適用性を いくつかのシミュレート計算によって検討した。結果 を要約すると以下のようである.
（1）抵抗力場の山を越して移動中の自由転位の速 度が巨視的応力速度に依存すると仮定し，負荷条件に よって定まる適正な数の自由転位が存在する定常変形 下での応力速度とひず速度の関係を与える速度平衡 式を導き，繰返し塑性変形下での応力ーひずみ曲線の 形状に及湾す応力速度およびひずみ速度の効果を明ら かにした。

（2）ひずみ速度あるいは応力速度が急変する過渡 期での遷移変形挙動は, 過不足を生じている自由転位 の数が負荷条件に適合して定まる自由転位の数に近づ く過程での挙動として系統的に記述することができ た.

（3）自由転位の速度特性を与える材料定数は遷移 変形過程を含む簡単な負荷条件による試験結果より容 易に評価できるものであった。

以上の結果㧍よび抵抗力場を表現する密度関数の特 性值 $S_{c o}$ と $m_{0}$ とは実験曲線より容易に評価できる ととを考えるなら，時間に依存する繰返し塑性変形举 動を統一的に記述する手法として本論文で提示したモ デルは実用的にも有効なものと考えることができる.

\section{文献}

(1) Krempl, E. and Kallianpur, V. V., J. Mech. Phys. Solids, 32-4 (1984), 301.

(2) Krempl, E. and Lu. H., Trans. ASME, J. Eng. Mat. Tech., 106-4 (1984), 376.

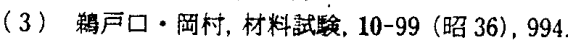

（4）小幡谷・河野，㙨論，51-463，A（昭 60)，952.

（5）小蟠谷・河野，譏論，51-467，A (昭 60)，1864.

(6) Johnston, W. G. and Gilman, J. J., J. Appl. Phys., 30-2 (1959), 129.

(7) Nadai, A., "Theory of Flow and Fracture of Solids", (1950), 315, McGraw-Hill, New York.

\section{討 論}

〔留间〕阿 部 武 治〔岡山大学工学部〕

次の点ご教示願いたい.

（1）本論文では，転位の速度がせん断応力速度に 依存すると仮定されている。一方, 金属学の分野など では，転位の速度はせん断応力に依存するとして取扱 われることが多いと思うが，そのような仮定から本論 文のような理論を組立てることは困難か。

（2）本理論は，応力速度がひずみ速度の関数であ るとする。いわゆる巨視的な哑弾性形の構成式(付 1) 関連があると考えてよいのか.
【回答〕（1）転位の移動速度がご指摘のような せん断応力に依存するなんらかの適切な関数て与えら れる場合にも本研究での論旨に沿った理論の組立は可 能と考えている。しかし，負荷-除荷過程が交互に繰返 される綝返し変形下においては転位の移動方向の反転 を伴うため, 単一方向の変形を対象とする場合とは異 なり転位の移動特性を単にせん断応力に依存するとと らえるよりむしろせん断応力增分 (せん断応力速度)に 依存すると考えるほうが自然ではないかと考えてい る.

（2）これまでの実験で得た一般的な力場の諸特性

(付 1) 例えば，德岡，機栈の研究，32(昭 55)，1211. 
値より考之, 式(21)の右辺 \{\} 内の第 2 項は応力 $S$ が $S_{c o}($ 安定したヒステリシスループでの降伏応力に 对応する)を越えない範囲においては方が特に大きく ない限り1に比べ十分小さな值となる。したがって， その場合には式 (22)が近似的に全ひずみ速度と応力速 度の一次線形の関係を与えるので，ご指摘の重弾性形 の構成式とほ浪一致すると考えられる。また一方，S が増加して塑性域に入った場合においても上述の項 $(\dot{s})^{1-n} f(s) / n_{0} v_{c} \eta の$ 値が1に比べ十分小さいような 条件すなわちs的小さい場合には亚弾性形構成式を 塑性変形挙動の表示に適用できることを示していると いえよう。

以上のことより，式(22)は特別な場合として垔弾性 形構成式を包含するものてあると考えることができ る。なお，整弾性形構成式の初期値の決定において本 研究で示した遷移変形過程の解析手法をそのまま適用 できるものと考えられる。

啓発的なご討論・ご指摘に深く感謝する.

[留問〕大野 信 忠〔豊橋技術科学大学〕

不規則障害物説に基づく繰返し塑性構成式が，速度 依存効果を記述できるように应張されており，與味深 く择読した．以下の点についてご教示いただきたい．

(1) 自由転位の移動速度を応力速度の関数とする ことによって速度依存効果を表現しておられるが，貴 理論における転位の移動速度を, 通常の理論のように 超過応力 $\sigma-\sigma_{s}\left(\sigma_{s}\right.$ : 準静的降伏応力)の関数とする と、なにか困難が生じるのか.またこの通常の方法に よって, 図 5〜8の現象が記述できないのか.

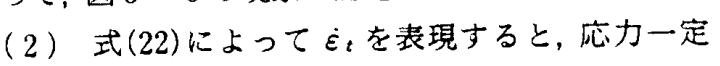

$(\dot{s}=0)$ の条件下ではクリープが生じないことになる. このことと, $2 \cdot 4 \cdot 3$ 項で述へておられるクリープとは, どのように関連しているのか.

(回筒）（1）転位の移動速度をご指摘のような 超過応力の関数と仮定することも可能と思われる。そ の場合, 式(17)での $v$ をそうした応力の関数(一般的 には応力 $S$ の関数で記述できる)におきかて得られ る以降の諸関保式を用いると, 図 5〜8に示す諸現象 の生じうることが定性的にではあるが容易に説明でき る.しかし, 繰返し変形下での洀静的降伏㐫力の評価 は多分に恐意的であることおよび本研究での自由転位 の移動速度は通常広く用いられている全可動転位の平 均的移動速度とは異なることなどを考慮すると, 適切 な超過応力の関数を実験的に決定するには相当の困難 を伴うものと考えている。

（2）式(22)の成立するのは式(23)でちえられる適 正な数の自由転位が存在することを前提とした定常変 形過程の場合である. $2 \cdot 4 \cdot 3$ 項で述べているのは定常 変形過程中に $s=0$ とした直後に生ずる時間に在存す る過渡的な変形挙動であり，その変形特性は一見遷移 クリープ挙動と類似しているものの，一般にいわれる クリープ挙動とはその成因機構が異なるものととらえ ている.なお，㐫力增加に基づいて生じた自由転位が すべて次の力場の山に到達した以降の一定応力レベル $(\dot{s}=0) に$ に抢变形挙動(定常クリープ)については 転位が熱振動の助けをかりて力場の山を越す効果を考 虑することにより検討できるので別途報告を予定して いる. 